\title{
Close to home: The drive for local food
}

\author{
Shawn A. Trivette, ${ }^{a}$ Louisiana Tech University
}

Submitted 24 May 2011 / Revised 17 January, 2 April, and 2 July 2012 / Accepted 12 July 2012 /

Published online 5 November 2012

Citation: Trivette, S. A. (2012). Close to home: The drive for local food. Journal of Agriculture, Food Systems,

and Community Development, 3(1), 161-180. http://dx.doi.org/10.5304/jafscd.2012.031.008

Copyright (C) 2012 by New Leaf Associates, Inc.

\begin{abstract}
One popular approach in the recent discussion around sustainable food systems has been to encourage a shift to locally and regionally produced food. The logic of doing this is multifold: locally produced food is good for the environment, helps a regional economy thrive, and provides a greater connection between people, their food, and those who produce it, which should also lead to equitable labor practices and greater food security and access. Yet for all of the benefits of a locally based food system, there are certain problematic elements inherent to some of these claims. In this paper I link these social, economic, and environmental elements through a review of what we know about locally based food systems as a function of sustainable agriculture. A careful examination of the literature shows that although local food systems hold considerable promise, they are not inherent mechanisms of sustainability.
\end{abstract}

\section{Keywords}

local food, social justice, sustainability

a Shawn Trivette, Department of Social Sciences, Louisiana Tech University; P.O. Box 9988; Ruston, Louisiana 71272 USA; +1-318-257-3069; trivette@latech.edu

\section{Introduction}

Over the last half century, many people have become aware of the host of environmental and social problems in the agro-industrial food systems and the way these food systems feed both America and the world. This growing awareness has driven the formation of many alternative agriculture movements, the latest iteration of which has been a call for more locally based food systems. Under the Obama administration even the U.S. Department of Agriculture (USDA) has gotten on board with this movement by creating new programs supporting locally based farmers and encouraging production for local consumption. In his examination of modern food systems in America, Michael Pollan (2006) follows his discussion of the industrial and organic food systems with a discussion of food localism, a trend in which people eat food produced close to home because of the social and environmental benefits this is supposed to bring, as well as how it can reflect a person's values regarding these (and other) perceived benefits. This move to eating locally is a relatively recent emergence in the nexus of alternative (and sustainable) food, especially when compared with the trend toward organic production and consumption.

Many people see local food as a panacea for 
the problems of the industrial systems, but this solution requires some close examination. When it comes to sustainable agriculture, local food systems offer a mixed bag. For the moment, let us define sustainable agriculture as agricultural practices that "meet the needs of the present without compromising the ability of future generations to meet their own needs" (Feenstra, Ingels, \& Campbell, n.d.); such practices, then, should be able to be maintained indefinitely without significant adverse consequences to the physical or social environment (Ikerd, 2007). While this definition is rather broad - and I give it further nuance below - it allows us to ask the following question: in what ways are local food systems examples of sustainable agriculture? That is, in what ways can local food systems offer a positive, long-lasting alternative to the harms of industrial systems, particularly on the surrounding physical and social environment? Although locally based systems have much promise as a sustainable food source, these systems are not without their pitfalls. As such, we should be wary of jumping on the local food bandwagon, as we run the risk of deifying the local as some sort of salvation to our dominant food systems' problems. As with most "wicked" problems (Rittel \& Webber, 1973), the question of how we sustainably feed ourselves is not one with so easy an answer.

My goal in this article is to review what we know about locally based food systems as one aspect of sustainable agriculture. By a local food system, I mean the food production, distribution, and consumption arrangements in which all elements of the system are parts of both a physical and social proximity intended to (re)connect these different elements in the same place (see Fonte, 2008). In meeting the goals of sustainability, there are things locally based systems do well and also ways they could improve. My central argument is that although local food systems hold considerable promise, they are not inherent mechanisms of sustainability. How, then, can they be improved? To address this, I begin with a brief review of the history behind our modern industrial food systems to provide context for the alternative and local food movements. I then discuss the logic of local agriculture and the kinds of problems such systems are supposed to solve as understood in three areas: environment, economy, and social responsibility. I conclude by highlighting some of the structural changes needed to see the development of a truly sustainable local food system.

\section{A Brief History of (Industrial) Food Production in the U.S.}

To understand the rise of alternative, and especially local, food movements, we must first have a basic understanding of how the industrial food system developed. The bulk of our modern food supply is built on a global food system, providing not only a wider variety of food than one region alone can produce, but also year-round availability of most foods. Conventional wisdom would have us believe that the current dominant system of food production in the U.S. is the best in all of history. Americans today (and others throughout the industrialized world) enjoy a plentiful supply of food with high variety. ${ }^{1}$ Further, many have this access consistently and uniformly: for example, fresh strawberries are available in winter (not just June, when they are in season in North America) and fresh tropical fruits like pineapple and kiwi can be found even in New England. These benefits, however, come at enormous, often hidden, costs.

U.S. food production has had a global element from its inception (Allen, 2004); much of the colonial system was geared toward supplying bulk goods and commodities to Britain. ${ }^{2}$ Nonetheless, up through the mid- $19^{\text {th }}$ century, a majority of the U.S. population was engaged in farming; today the opposite is true (Bureau of Labor Statistics [BLS], 2010; Lobao \& Meyer, 2001). Regular booms in agricultural and other markets throughout the late $19^{\text {th }}$ and early $20^{\text {th }}$ centuries encouraged farmers to plant more crops in subsequent years, which routinely created food surpluses. Since food demand is closely tied to population size, and does not easily grow or shrink via other influences (see Cochrane,

\footnotetext{
${ }^{1}$ It is important to note that this access depends largely on one's class standing and social location; many of the urban poor in the U.S. do not even have easy access to a grocery store, thus limiting the true "variety" of foods they consume. 2 Murray (2007) notes how the global food trade has existed at least as far back as the Roman Empire with the trade of olive oil from Spain throughout the Mediterranean region.
} 
2003) this served to drive down food prices. ${ }^{3}$ These boom periods, however, led to periods of bust as many farms experienced economic collapse, driving many people to migrate from the rural countryside to cities to seek employment. Increasing industrialization created jobs in the cities, further helping to draw farmers off the land (Andrews, 2006; DuPuis, 2002). While some farm organizations, even before the Great Depression of the 1930s, encouraged farmers to voluntarily limit production in response to shrinking markets (Andrews, 2006, p. 161), they met with little success. These inadequacies in a voluntary system of control ultimately brought about many of the agricultural stabilization policies of the New Deal era of the late 1930s into the 1940s (Andrews, 2006; Rasmussen, Baker, \& Ward, 1976).

New Deal agricultural stabilization programs were designed to reduce acreage planted, fix market quotas, levy taxes, purchase surplus crops, and even remove certain lands from production. These systems were designed to regulate prices (for the benefit of farmers) and conserve soil. However, they only applied to a few basic commodity crops (such as corn, soybeans, and grain). Further, these price-fixing mechanisms often raised the immediate cost to consumers. They also created incentives for farmers to intensify production on their land, thereby defeating the market stabilization goal as well as allowing them to increase their capital gains (not to mention the further environmental destruction due to fertilizer and pesticide use). Essentially, farmers did not trust the system to provide them with a means of survival. Thus federal policies from the World War II years onward, which were designed to limit production, have instead stimulated the overproduction of certain foods (Andrews, 2006).

These subsidies gave farmers, especially those who managed to consolidate into ever larger production units, considerable wealth. Many other players in the agricultural system, such as the agricultural supply industry, also benefited. This

\footnotetext{
${ }^{3}$ As one reviewer points out, the critical assumption here is the capacity for overproduction compared to demand. This assumption may be problematic in the face of things like climate change, population growth, and biofuel production.
}

wealth, coupled with growing political influence, has helped perpetuate a system of low environmental regulation with respect to agriculture. ${ }^{4}$ In addition, government support of these subsidized crops began to push many remaining farms into intensive production of primarily - and in some cases only - those crops. This increased the overproduction and contributed to the further deterioration of prices for subsidized crops and the increased need of the government (and therefore taxpayers) to support farmers who produce those crops (Cochrane, 2003).

World War II brought about many changes in consumption patterns that have lasted well into the $20^{\text {th }}$ and $21^{\text {st }}$ centuries. During the war, troops needed food supplies. One factor related to the war effort (although also a consequence of the rise of mechanized farming methods) was an increase in domestic food production. Farmers were given increased subsidies to encourage the needed excess production of selected crops (Andrews, 2006). Following the war, these increases further contributed to the economic problems of food surplus, which carry forward into today (Friedmann, 2002). The federal government attempted to deal with this overproduction by diverting it first to welfare relief and school lunch programs and later to food aid for post-colonial countries, practices that still exist today though the National School Lunch Program and the Food for Peace Act (P.L. 480). These international donations weakened farm prices and undermined the farm economies of recipient countries, thereby encouraging urban growth as impoverished farmers moved to the cities for work (Warman, 2003). Ultimately, what appeared to much of the American public to be gestures of goodwill and humanitarian relief were actually attempts to hide a politically embarrassing situation: domestic surpluses stimulated by government subsidies and policies ${ }^{5}$ (Andrews, 2006).

\footnotetext{
${ }^{4}$ Agriculture is not the only industry for which this occurred. Other industries include automobile, steel, and rail transport, just to name a few (Andrews, 2006).

5 A 1996 "freedom to farm" bill would have phased out crop subsidies that had come to benefit only a small number of large corporations at the expense of taxpayers, the environment, and small-scale farmers. However, the farm lobby convinced Congress to instead increase subsidies via
} 
Also during the war, U.S. troops could not be fed off the land in which they were located, because it was often heavily damaged by the war and not capable of supporting even the local population. To address this problem and the difficulty of long-distance food transport, scientists developed many ways to package and preserve food while keeping it lightweight so that it was easy to ship and easy to carry (Murray, 2007). This technological drive for lightweight food continues in military and space research today. Many of these technologies are now found in the public sphere, encouraged by and encouraging many people's increased desire for convenience, travel, and mobility. This has been fueled (literally and figuratively) by the low cost of transportation, largely through cheap oil and the ubiquity of refrigerated transport. Between cheap transport, abundant food processing and packaging technologies, and continued technological advances in farming - what Buttel, Larson, \& Gillespie (1990) refer to as the Treadmill of Technology - it is now easier and cheaper to grow food at a large scale and ship it than it is to diversify and feed ourselves from a certain locality.

\section{The Logic of Local}

Out of this increasingly globalized and industrialized food system has emerged an alternative, and some would claim sustainable, food movement. From its inception with J. I. Rodale in the early 1930s through the early 1990s, alternative food has largely been equated with organic food. Proponents of such approaches challenge conventional agricultural production and consumption patterns by focusing on natural processes to grow food that is healthy to the earth and healthy to eat (that is, not contaminated with synthetic chemicals). The rise of the organic movement is well documented (Duram, 2005; Fromartz, 2006; Pollan, 2001, 2006; Raynolds, $2000^{6}$ ). Beginning as a fringe movement

“temporary emergency payments.” By 2002, a congressional election year in which the farm bill was due for reconsideration, most politicians (especially those from farm states) were instead promoting subsidy increases in order to garner votes (Andrews, 2006).

${ }^{6}$ Raynolds also discusses the fair trade movement, which focuses on "equitable social relations." She argues that fair and experiencing considerable animosity for a long time from mainstream institutions like the USDA, land-grant universities, and major farm organizations, it was only in the mid-1980s that organic food caught on in more mainstream circles. As language related to organic and sustainable farming was gradually added to the 1985 and 1990 Farm Bills (Youngberg, Schaller, \& Merrigan, 1993), organic farms and food processors across the country began to go the way of conventional agriculture: smaller operations, particularly in areas of the country with land and conditions suitable for large-scale production, were bought up by major industrialized food producers, while larger conventional producers simply transitioned part of their land to organic production while maintaining an otherwise industrial operation. These trends have continued to this day such that now much of our organic food supply is part of an industrial, albeit organic, food chain (Howard, 2009; Raynolds, 2004). Further, many (although not all) of the environmental externalities associated with the conventional industrial food chain have carried over into the industrial organic system, making the environmental benefits of large-scale organic only marginally better than their conventional counterparts (Cuddeford, 2003; Guthman, 2004b; Obach, 2007). In other words, the counterculture movement of organic food was co-opted and mainstreamed by the industrial food chain, making it considerably less "alternative" than it once was (Campbell, 2001; Guthman, 2004a, 2004b; Pollan, 2006; Walker, 2004). The clearest example of this mainstreaming is that since 2002 the USDA, with primary input from large agribusiness interests, has determined what qualifies for the organic label (Deaton \& Hoehn, 2005; Pollan, 2006).

While this standardization was ostensibly an attempt to clarify what organic means among what were - and still are - a variety of competing definitions, the meaning of organic is still hotly contested. While federal standards focus primarily on input substitution (i.e., using manure and compost instead of synthetic fertilizers), many alternative food advocates see organic in a more rigorous

trade is better than organic as an oppositional movement by its focus on relations of trade and distribution. 
and holistic manner (i.e., ensuring farm ecosystem integrity through maintaining soil fertility, preserving the water supply, and protecting human health and species diversity; see Crews, Mohler, \& Power, 1991). Recognizing that mainstream definitions of organic do not describe production systems that are demonstrably sustainable, many in the alternative food movement have advocated for an expansion or even a shift in focus to locally based food systems, arguing that locally based food would be both more sustainable than organic and more difficult for conventional interests to co-opt (Guthman, 2004b; Halweil, 2002; Hines, 2000; Hines, Lucas, \& Shiva, 2002; Kloppenburg, Hendrickson, \& Stevenson, 1996). While the co-optability of local food is beyond the scope of this paper (although some recent scholarship indicates that the concept is not nearly as safe as some believe; see, for instance, Fonte, 2008), my goal in this paper is to evaluate the merits of locally based food systems as sustainable alternatives to the conventional food system.

I consider locally based (or locally oriented) food systems to encompass food that is intended for consumption within the same area that it is produced. This element of intentionality is important in distinguishing local food as an orientation to food production and consumption rather than simply the food that is available in a particular area. Often local food is marketed on the basis of shared values between farmers and consumers, although I do not include this element in my definition primarily because of the variation in how different actors may value local food, including (or not) such qualities as environmental benefits, local economic development, and personal health. While the definition of what constitutes "local" is openended and may vary depending on whom one asks (and has been conceptualized as everything from a radial distance of 50 or 100 miles to a collection of states, like New England or the Pacific Northwest), local by this understanding is a social proximity in which producer and consumer are connected to the same place (Fonte, 2008). This way of understanding local food also distinguishes it from a perspective that places value on a product's origin for use in distant markets, such as Vermont maple syrup or Palizzi wine from Italy, though both may be found in many places throughout the world (Fonte, 2008).

It is important also to further clarify my initial definition of sustainable agriculture. Beyond simply avoiding adverse consequences to the physical and social world, sustainability is broadly seen as consisting of three main components: ecological and environmental soundness, economic viability, and social responsibility (particularly in light of social and economic justice), which often also includes human health as well as the ability simply to provide enough food. I further articulate the details of each element below. Additionally, it is helpful to think of sustainable practices and orientations as existing along a continuum rather than being absolutely sustainable or not sustainable; that is, certain practices can be more or less sustainable than others depending on to what extent they align with the hallmarks of these three pillars. I turn now to an examination of locally based food in light of each of these three legs of sustainability, highlighting the main points advocates make in favor of local food systems and empirical evidence that either supports or refutes them.

\section{Ecological and Environmental Soundness}

The environment is perhaps the first thing people call to mind when they think of sustainability. Indeed, environmental stewardship has been a central focus of the alternative agriculture movement since its inception (Crews, Mohler, \& Power, 1991). In a globalized and highly corporatized food system (O'Hara \& Stagl, 2001), an emphasis on producing as much as possible leads to agricultural practices that are destructive to the environment in numerous ways (see also MacCannell, 1988, pp. 25-26). It is for this reason that in the early years of the alternative agriculture movement sustainability was understood mostly in terms of organic agriculture: organic practices are about treating the land well and minimizing and eliminating farming methods that harm the soil and surrounding environment. However, organic food is not the only way in which we can understand ecological soundness. Locally produced food also promises several environmental benefits as a response to the industrial system, including shorter transportation lines and a reduction of the destructive patterns of large- 
scale production. Though I will address these areas separately, we must bear in mind that they are interrelated.

\section{Shorter Transportation Lines}

One of the natural consequences of the concentration of our food supply is the necessity to transport it long distances (Pirog, van Pelt, Enshayan, \& Cook, 2001). This need for increased transport carries with it the need for fuel as well as proper means of storage so that food stays fresh until it arrives at its destination and then makes its way into the hands of consumers. Much of the energy required for this currently comes in the form of fossil fuels, which highlights the problem of using nonrenewable resources and generating greenhouse gases (Hines et al., 2002; Peters, Bills, Wilkins, \& Fick, 2008). The concept of food miles offers us a way of thinking about the distance our food travels (Iles, 2005; Paxton, 1994). Simply put, the measure of food miles is the number of miles a given piece of food had to travel from its source of production (the farm) to its final destination (the plate). Many scholars and activists use the term food miles as a proxy for the environmental impact our food has simply by the resources it uses to travel from one place to another. They argue that it is more environmentally friendly to consume food grown within a local foodshed, ${ }^{7}$ because of its low food miles, than food that has been shipped vast distances (Brown, 2003; Feenstra, 1997; Kloppenburg et al., 1996; Kloppenburg \& Lezberg, 1996; Lea, 2005; Lezberg \& Kloppenburg, 1996; Vogt \& Kaiser, 2008). Of course, the strength of this argument depends upon a variety of factors besides simply distance traveled, such as the means of transport and the amount of food delivered.

Food miles may be a useful concept for increasing agency and responsibility in food choices, but it does have important limitations. For one thing, what counts as local is often quite difficult to determine (see Hinrichs, 2003; Iles, 2005; Selfa \& Qazi, 2005). How do we account for items

\footnotetext{
7 The term foodshed was first coined by Walter Hedden (1929) and reintroduced by Arthur Getz (1991). Similar to Hedden, Getz outlines a foodshed simply as "the area defined by a structure of [food] supply."
}

considered essential to an area yet not fully produced there? How do we even define what constitutes a foodshed? Peters et al. (2002) and Pirog et al. (2001) attempt to resolve these questions for the states of New York and Iowa (see also Thompson, Harper, \& Kraus (2008) for an assessment of the San Francisco area), yet these studies highlight the very difficulty of finding an answer: it is very complicated to get the seemingly basic data for such supposedly simple concepts.

Perhaps more fundamentally, however, a focus on the local may in some ways leave out other aspects of sustainability, such as the means by which an item is produced or the economic conditions of production (i.e., fair trade). In other words, environmental impacts may not be totally represented by food miles (Edwards-Jones et al., 2008; Oglethorpe, 2010). For example, transportation is not the only - or even the greatest - foodrelated contributor to greenhouse gas emissions (Edwards-Jones et al., 2008; Heller \& Keoleian, 2003; Weber \& Matthews, 2008).

In short, food miles may be a useful concept, but its use as a tool is limited by the degree to which insights gained from it can be applied to change agricultural systems to actually make them more sustainable (Iles, 2005). As a means of reducing energy inputs and pollution generated in long-distance transportation, local food shows considerable promise. Insofar as locally oriented food reduces transportation lines, consumption of fossil fuels and emission of greenhouse gases will also be reduced. However, the distance food travels is but one aspect of a complex system of food production and it is imperative that future studies on energy expenditure in both local and nonlocal food production account for this more holistic picture (Duram \& Oberholtzer, 2010).

\section{Reduction of Scale}

The economic logic of mass production often necessitates production on a large scale; in 2007, though average farm size in the U.S. was 418 acres (169 ha), of the 2.2 million farms in the country, almost 200,000 were larger than 1,000 acres (405 ha) (U.S. Department of Agriculture [USDA], 2009). As the agricultural scale increases, new considerations about and methods of growing and pest 
control must be taken into account. Large-scale farming in the U.S. typically involves the use of heavy machinery that allows one person to plant, maintain, and harvest vast areas in a relatively short time. However, these machines damage soil structure more readily than smaller equipment or draft animals, have the potential to accelerate erosion, increase silting of waterways, and necessitate the use of fossil fuels (depleting a nonrenewable resource and releasing greenhouse gasses into the atmosphere).

Proponents of local food systems claim that such systems tend to be small scale, which minimizes the need for heavy machinery and the destruction they cause. While it is true that smaller farms have lower environmental impacts than larger ones (Altieri, 1995; Bell, 2004; Rosset, 1999), the evidence linking locally oriented and small-scale farms is less clear. Large-scale farms can (and certainly do) provide for their local communities, though their primary orientations tend to be toward mass markets (Bell, 2004): "in an industrial farm context...the agricultural economy is integrated into the world system and becomes detached from the local rural community" (MacCannell, 1988, p. 57). Indeed, this orientation of large-scale farms to long-range markets supports the notion that locally oriented farms are more likely than nonlocally oriented farms to be of relatively smaller scale. And it further stands to reason that small-scale farms may have a shorter range of distribution due to their limited supply of goods relative to larger farms. We should be cautious, however, in assuming that this link between smallscale and short distribution range is necessarily so; consider, for example, small farms that specialize in a rare or very durable product, which may market its goods over a wide region. Inasmuch as locally oriented farms are smaller than mass-market farms, their need for large machinery is also minimized, as is the destruction such equipment causes. However, further research is needed to clarify exactly what connection exists between local orientation and small-scale. Further, while this discussion of "small scale" suggests some sort of discrete type or size, scale is more accurately a continuous variable and contingent upon the practices being used and the products being grown, fed, or produced.

\section{Local Food and Organic Production}

Organic food production is often argued to have a net environmental benefit relative to conventional production, if for nothing else than because organic production prohibits the use of synthetic fertilizers and pesticides that damage surrounding soil and water resources (Allen, 1993; Glaeser, 1997; Nierenberg, 2003). Though organic production today is done increasingly on an industrial scale oriented toward a wide-ranging market, early organic advocates often argued that part of the organic movement entailed consuming food close to the source of production (Belasco, 2007).

While not all locally oriented farms are certified organic, a much higher proportion of them tend to be than those which provide for the national and global markets; one large survey finds that approximately one-third of farms selling at farmers' markets are certified organic (Kremen, Greene, \& Hanson, 2003) while another study cites as much as 90 percent of $\mathrm{CSA}^{8}$ operations farming organically (Union of Concerned Scientists, 2004); however, it is unclear if all of these farms are certified organic. Compare this to estimates that less than 4 percent of the overall U.S. food market currently goes to organic sales (Organic Trade Association [OTA], 2010). ${ }^{9}$ To the extent that locally oriented farms are more likely than mass-marketoriented farms to promote organic practices (whether certified organic or not), any adverse impact on the surrounding environment will also be minimized. However, similar to the discussion of farm scale, farms may engage in a variety of ecologically sound production practices independent of their market orientation; while locally based

\footnotetext{
${ }^{8}$ CSA stands for community supported agriculture. A CSA operation is a farm in which customers purchase a membership, usually before the start of the growing season, in return for typically a weekly share of produce or other products from the farm. Such arrangements allow farmers much-needed capital (especially in the off-season when money may be tight) and are considered effective ways of distributing the unpredictability and uncertainty of farming more equitably among the community. See Henderson, 2007, for more on CSAs. ${ }^{9}$ It is worth noting that many locally oriented farms not certified organic may nonetheless be employing organic practices without having obtained organic certification. They may refer to themselves with terms that are not regulated by a particular body, such as "beyond organic" or "natural."
} 
food systems may have a tendency toward such practices, local and organic do not necessarily go hand-in-hand.

So how does local food stack up in terms of promoting environmental soundness? There is some evidence that locally based food is much more likely than food from the conventional system to be organic, which can mean at least some net environmental benefit. And local food's low food miles show a potential environmental benefit in terms of reduced transportation needs, depending on exactly how such a system is configured. However, there are certainly other significant aspects of the agricultural system that impact the climate-energy picture that are not captured in a focus on local food, including the link between local food and small-scale farming. On the whole, then, locally based food systems do show potential for promoting some environmental aspects of sustainability, but these need to be understood as part of a broader approach to food production.

\section{Economic Vitality}

In addition to being ecologically sound, sustainable agriculture systems must also be economically vital (Ikerd, 2007); a system cannot be considered sustainable if its producers are unable to economically provide for themselves. To contextualize this, I first examine some of the economic hardships created and exacerbated by the industrial food system. Recall that federal policies and subsidies encourage mass production and oversupply. Such practices mean lower prices (at least for farmers, if not consumers) and thereby favor large farms and agribusiness. This actually serves to limit market possibilities, thus making it harder for smaller producers to compete and driving them out of business ${ }^{10}$

\footnotetext{
10 These economic difficulties and structural impediments impact agriculture in less industrialized nations as well (Gellerman \& Curwood, 2007; O’Hara \& Stagl, 2001), in part because the major corporations that control most food supplies are multinational ones, with decreasing attachment to the parent nation-state (Bonanno, Busch, Friedland, Gouveia, \& Mingione, 1994; for some examples, see Hines et al. 2002, Lang, 1996, and Nierenberg, 2003). If the multinational corporation is effectively outside the bounds of the state in terms of regulation, then it highlights an important limitation
}

(Norberg-Hodge, 1998; Stephenson \& Lev, 2004). The rise of supermarkets has added to the loss of market possibilities since it is much easier for large businesses to source material from one or two major distributors that can reliably ensure access to whatever may be desired than it is to work with many small farms which may have varying levels of crop availability (Halweil, 2002). This principle applies not only to supermarkets, but any institution purchasing large quantities of food, such as large restaurants, office cafeterias, and university dining services. Small farms have a difficult time competing with the availability and convenience provided by agribusiness. ${ }^{11}$

The "solution" for many farmers has been to contract through large agri-business firms, at least where such options are available. This means an ability to continue farming (and often retain their land) but at a cost of lower income and often a need to find other employment (Bell, 2004; Cochrane, 2003). Though the question of fair trade is typically only considered in regard to internationally produced goods, such as coffee and tropical fruits, it also needs to be asked of domestic producers: are they being paid a fair and livable wage for their work ${ }^{12}$ ? If they are part of the industrial agriculture system, the answer is often no.

It is this set of economic difficulties that locally based food systems purport to remedy. Advocates of locally based agriculture claim that such systems meet the requirement of economic vitality because they support small-scale and family farms and help a regional economy thrive. The ability of local food to support a regional economy makes sense. Purchasing food locally keeps money and capital circulating within a region, rather than going to a corporation with headquarters elsewhere ${ }^{13}$ (Feenstra,

\footnotetext{
of the ability of policies to effect sustainable change in agricultural systems (Bonanno \& Constance, 2006).

${ }^{11}$ NAFTA and other free trade agreements have also negatively impacted agriculture by encouraging centralization of food processing in areas where labor is cheapest - leaving other producers out of work (McDonald, 2002).

12 Though asked in terms of economic vitality, such a question is also one of social justice.

${ }^{13}$ As an example of counterpoint, consider the impact of excess U.S. food production on the international stage. In an effort to deal with our national oversupply of food, the excess
} 
1997; Halweil, 2002; Hines, 2000). Similar examples of this phenomenon can be seen in other local economies that are not necessarily food-related (Gibson-Graham, 2010; Hess, 2009).

The ability of local food to support small-scale and family farms is less certain, for reasons similar to the unclear link between local food and smallscale production discussed above. Nonetheless, even if we assume for a moment that local food and small-scale are more or less equivalent, the ability of local food arrangements to support smallscale, family farms faces considerable structural hurdles (Lyson, 2004). The very policies that support large-scale agriculture serve to undercut smallscale producers because of how they ultimately influence both individual and institutional food consumers: through pricing and sourcing. The scale of the industrial food system allows for greater ease of distribution and delivery than smaller farms can provide (Guthman, Morris, \& Allen, 2006; Hinrichs, 2000). Even ignoring a farm's size altogether, farms with an orientation toward a wide-ranging market are better prepared to handle changes and upsets in that market than are farms geared primarily or solely toward local distribution and consumption.

Given these constraints, what makes local food work as an economically viable operation is the choice that consumers make to invest in such a system. While numerous studies show that many consumers do indeed want local food (Bond, Thilmany, \& Bond, 2006; Brown, 2003; Institute of Agriculture and Natural Resources [IANR], 2003; Izumi, Rostant, Moss, \& Hamm, 2006; Schneider \& Francis, 2005; Sonnino, 2009; Starr, Card, Benepe, Auld, Lamm, Smith, \& Wilken, 2003; Stephenson \& Lev, 2004; Vallianatos, Gottlieb, \& Haase, 2004; Vogt \& Kaiser, 2008), their reasons for it are variable enough that some could potentially be met through nonlocal means (such as quality or concerns over food safety). Crews,

food that is not turned into value-added products is sent into the world market, sometimes for sale and sometimes as food aid. As external products flood a given market, farmers in the region are driven out of business, thus losing their income base. Further, money used to pay for the newly arrived food does not stay in the local economy. With money leaving the area, soon everyone's ability to pay for food is reduced.
Mohler, and Power (1991) suggest that economic viability (or profit) may not be a useful criterion of sustainable agriculture in part because markets are unstable. This instability can be seen both in the potential for changes in laws and policies that provide economic support to certain activities, as well as something as basic and unpredictable as a shift in consumer preferences. Crews et al. further argue that:

If we use both economic and ecological criteria to define sustainability, progress toward ecological sustainability almost certainly will be hindered. We should work toward structuring society in such a way that sustainable agricultural practices are profitable (for example, by modifying commodity programs to end incentives for continuous corn cropping), rather than including profitability within the definition itself. (Crews et al., 1991, p. 149)

What makes local food systems economically viable, then, is an interest on the part of consumers in that locality to purchase locally. Insofar as they are willing to do so, such purchases do show the potential for significant benefit to the economic prosperity and stability of the community as a whole. However, as I discuss below in the section on social justice, this benefit may not apply equally to all participants. Considering this and the caution by Crews et al. (1991), perhaps economic considerations are less a central component to sustainable systems and more an artifact of the way those systems are established. Focusing too heavily on the need for profitability may be a distraction from the problem of sustainability, since profitability for different actors can be factored into a system in a variety of ways.

\section{Social Responsibility}

The third and final leg of sustainability is social responsibility (Ikerd, 2007). There is very little purpose in seeking to live sustainably if we don't remember for whom we seek to do so: people. The socially responsible promise of local food is that such systems ensure that people have an adequate amount and variety of safe, healthy, and nutritious 
food, linking locally based systems to questions of public health and food security. Though not exactly a function of social responsibility, I also consider here the claim that locally based systems generate greater social connections between consumers and producers. I begin this section by employing a social justice framing to consider how local agriculture does and does not provide food security. ${ }^{14}$ Following this, I briefly examine the feasibility of locally based food systems to address concerns of public health. Lastly I review the limited empirical evidence for the increased social networks claim.

\section{Social Justice in Local Food:}

Food Security and the Local Trap

Food security can be defined in many different ways, but at its core it is about the ability of people to legitimately and consistently procure the food they need. The inability to readily access food is a social health problem known as food insecurity. Food insecurity can be understood on two levels: when the supply of food to a particular place is disrupted, and when people are unable to afford or access food by legitimate means, even if it is otherwise physically available. Locally based agriculture is often argued as ensuring greater food security, both in terms of regional security and individual food access (see Enshyan, 2004; Lang, 1996; Thilmany \& Watson, 2004). In this section I address each of these considerations in turn.

Our large-scale food production systems force us to rely on a very centralized supply. For example, should some extreme event (such as a terrorist attack or major weather event) cause the disruption of food supplies for even more than two or three days, many of our large urban centers would soon find themselves in a dire situation, as most large cities have a low-reserve food supply (Halweil, 2002; Henderson, 2007; Hines, 2000). Such potential danger is a powerful argument in favor of regionally reliant food systems. Ideally, locally

\footnotetext{
14 Another important aspect of social justice that I do not consider here is gender equity in involvement in sustainable agriculture systems (see Cone \& Myhre, 2000; DeLind \& Ferguson, 1999; Hall \& Mogyorody, 2007; Meares, 1997; Peter, Bell, Jarnagin, \& Bauer, 2000; Trauger, 2004).
}

based food systems should be capable of feeding a given region's population; however, because of the current format of agricultural production, many regions in the U.S. would likely need significant infrastructural development and agricultural rearrangement to realistically provide for their own localities (see Peters et al., 2002, and Pirog et al., 2001).

In addition to providing enough food for a given region's population, food security also entails that such systems be able to provide enough food in a way that all people in that region are able to physically and financially access that food. Currently in the U.S., hunger and malnutrition are due largely not to lack of availability of food, but to social policies regarding welfare and the poor - in other words, access is the key to dealing with hunger. Somewhat paradoxically, while the consolidation of agricultural production in the U.S. has led to a food abundance for many U.S. citizens, it contributes to malnutrition and hunger both domestically and in nonindustrialized parts of the world ${ }^{15}$ (Nestle, 2002). Proponents of local food systems often argue that provisioning food locally is a way to ensure that all people within that locality will be fed.

It is on this point that proponents of local food are perhaps the most susceptible to being challenged. Local food systems (especially directto-consumer enterprises like CSAs and farmers' markets) are often charged with being elitist developments. CSA memberships, for example, typically consist of well-educated, high-income families ${ }^{16}$ (Cone \& Myhre, 2000; O’Hara \& Stagl, 2001); further, both CSAs and farmers' markets have low institutional capacity to provide food security to low-income residents (Guthman, Morris, \& Allen, 2006). This is due to a variety of barriers to access, most notably price and available time and means of

\footnotetext{
15 The flooding of global markets is one major reason so many people in the world are hungry (Lang, 1996; Mancus, 2007; Lezberg \& Kloppenburg, 1996). The tragic irony is that although the available food is even cheaper to purchase than if it had been produced by local farmers, most people find themselves unable to afford it.

${ }^{16}$ See Hinrichs and Kremer (2008) for an examination of a CSA-related outreach program designed to increase participation of low-income families through a subsidy program.
} 
transportation. While such barriers and disparities are mainly products of the structure of the larger food system, without a change to said system, it is worth considering who has access to local food arrangements; generally speaking, it is the more affluent segments of the population.

The potential pitfall inherent to the logic of local food is what Born and Purcell (2006) call the "local trap." The local trap is the assumption that regionally based (and presumed small-scale) agriculture is de facto ecologically sustainable and socially just; however, this correlation is not necessarily true. Rather, sustainability and justice come out of particular agendas that may use the ideas of large and small scales (and local and global) strategically. DuPuis and Goodman (2005) make a similar argument: they do not deny the political power of the local as a force against globalization, but they do recognize the parochialism and elitism that can come from an un-interrogated understanding of the local (see also Allen (2004) and DuPuis, Goodman, and Harrison (2006)). In other words, food relocalization can be problematic if questions of social justice are left invisible. People derive a variety of meanings from localism. While it can encourage receptivity to difference and diversity, it can also be parochial and defensive (Hinrichs, 2003; Winter, 2003).

Rather than rejecting localism, DuPuis and Goodman argue for a reflexive localism that harnesses the power of the local while struggling against inequality in local arenas. "An inclusive and reflexive politics in place would understand local food systems not as local 'resistance' against a global capitalist 'logic' but as a mutually constitutive, imperfect, political process in which the local and the global make each other on an everyday basis" (DuPuis \& Goodman, 2005, p. 369). Hess (2009) tackles this issue more concretely by highlighting some major critiques to the social justice side of localism (namely that localism benefits wealthy families, communities, and nations at the expense of less affluent ones) and discussing ways localism can potentially address these critiques so as to not fall further into the local trap (for example, through low-income scholarships or slidingscale memberships to CSAs, farmers' markets accepting food stamps, and fairly traded goods).
The Public Health Benefits of Local Food

Part of the socially responsible (some might even say social justice) promise of locally based food systems is providing safe and healthy food in safe and healthy ways. Just as the high concentration of conventional food production generates environmental hazards, so does it also generate public health hazards, both in terms of the food available to us and in the ways in which it is produced. For example, increasingly frequent and widespread food contamination scares (resulting in illness and even death in the human population) have been linked to problems in the conventional food production system (Altekruse, Cohen, \& Swerdlow, 1997; DeLind \& Howard, 2008; Tauxe, 1997; Waltner-Toews, 1996). This is not to suggest that food contamination cannot occur in locally oriented systems, but the range and likely severity of its impact would be considerably less than such contaminations in the conventional system. ${ }^{17}$

Some people participate in local food as a way of avoiding the problems (and perceived risks) in the rest of the food system. This is what Szasz (2009) refers to as the Inverted Quarantine: we use commodities to shield or insulate ourselves from the outer environment. We do this with organic food in an attempt to avoid pesticides and other harmful chemicals, and we do this with local food as well, to avoid yet other unknowable risks (Bonanno et al., 1994; Knight \& Warland, 2005; Szasz, 2009). In an attempt to remove themselves from that potentially harmful system, some people shop with local food in mind.

It was a similar logic of risk assessment and avoidance that drove us from the regional food supply systems of earlier centuries and decades. DuPuis (2002) highlights this through the lens of milk production and what she calls the Perfect Story: increasing technological innovation will

\footnotetext{
${ }^{17}$ While not something that advocates claim locally based food systems are able to solve (and therefore also beyond the scope of this paper), there are other health problems associated with industrial food production. Many overproduced products, especially corn, are processed into now-ubiquitous value-added food goods, such as high fructose corn syrup. Such products are considered a primary reason the United States is experiencing what some have called an obesity epidemic (Jennings, 2003; Nestle, 2007), with links to a host of medical problems.
} 
increase our food supply and protect us from harm. In her discussion of the rise of modern industrial agriculture, she argues that a major drive behind this shift was the "industrial bargain": an alliance between consumers, mass-production capitalists, and intensive farmers to create a system of cheap nutrition (p. 89). But we can see the imperfections in this Perfect Story as consumers now have come to question the sources of their food and try to make sense out of a complicated yet minimally available realm of information (see also Blay-Palmer, 2008).

There are many things in our day-to-day life that are outside our control; consuming local food is one way rational actors try to deal with this. Yet it is very difficult to step completely outside the system and live apart from it. Even if we try, we find ourselves confounded by the systems from which we are trying to separate. Local food is no different. While consuming local food as a way to avoid the broader risks of the industrial food system might work on an individual level for some, local food is not immune from problems like food contamination. This type of green consumption provides a sense of personal responsibility and empowerment with respect to environmental risks while also incurring doubts and insecurities about choices made (Connolly \& Prothero, 2008). Again we see a need for a reflexive localism that allows us to approach potential solutions to the problems of our dominant food system with a societal view in mind rather than one that only considers the individual level.

\section{Local Agriculture and Social Networks}

Perhaps the most difficult to assess claim of local food advocates is that locally based systems create greater connections among people, and sometimes greater connections between people and their food (see Halweil, 2002; Henderson, 2007; Hines, 2000; and Pollan, 2006). There is evidence that many local food participants believe in the potential for these increased connections (Cone \& Myhre, 2000; DeLind, 1999, 2002; Wells, Gradwell, \& Yoder, 1999), and studies dating as far back as the 1940s suggest that communities with small (though not necessarily locally oriented) farms have stronger community ties and higher levels of civic engage- ment than those with large farms (Goldschmidt, 1946; Lobao, Schulman, \& Swanson, 1993; MacCannell, 1988; MacCannell \& White, 1984). One not-insignificant challenge in assessing this claim of greater social connections is determining and measuring a basis of comparison. That is, when we say local food systems generate greater community ties, to what are we comparing these connections? Further, how are we to measure the prevalence of said connections? The concept of "greater connections" is an excellent rhetorical and philosophical device, but lends itself to very little empirical substance. In fact, there is some evidence that this claim has some key limitations. Though local markets may encourage human connections and direct interaction on some level, they are still places where relationships can be commodified by providing an alternative to "monoculture market economy" without challenging the fundamental commodification of food (Hinrichs, 2000). Further, one primary reason many people do not participate directly in local food systems is because it lacks convenience: they want food to be available when and where they desire (Cone \& Myhre, 2000; Schneider \& Francis, 2005; Stephenson \& Lev, 2004). For example, for families who participate in a CSA one year but do not renew their membership the following year, the inconvenience factor is the primary reason: working with in-season produce each week requires a significant change in most people's lifestyles (Cone \& Myhre, 2000).

If we broaden our scope from local orientation to include a variety of practices often included under the purview of sustainability, then it is possible to speak to the kinds of social networks necessary and inherent to the production of sustainable agriculture knowledge, at least among farmers and producers. If Lyson's (2004) understanding of the intersection between sustainable and local food holds true (what he calls civic agriculture), then such a shift in focus makes sense, as what we know about social networks as a function of sustainable practices should similarly hold true in locally based food. It is an open-ended question, however, whether such links between sustainability writ large and producer social networks also apply when the focus is restricted to locally oriented food systems and also whether such networks occur among con- 
sumers as well. Nonetheless, I present here a brief review of the literature on sustainable practices as broadly conceived and their impact on social networks.

What we know about sustainable agriculture knowledge and social networks comes from research on farmers and food producers. Some scholars (Brodt, Feenstra, Kozloff, Klonsky, \& Tourte, 2006; Lyson \& Guptill, 2004) argue that conventional and sustainable farmers approach farming from fundamentally different paradigms, and that these paradigms impact farmers' interest in and willingness to engage in practices considered part of sustainable agriculture. ${ }^{18}$ On the other hand, some scholars argue that farmers are reflexive actors who navigate expert and local knowledge in their decisions whether to adopt certain practices, whether to adopt the latest technological trend (such as Bt corn) or a new (possibly sustainable) method, and are more likely to be influenced by first-hand or local experiences than by state or expert observations (Bell, 2004; Kaup, 2008). Regardless, there is ample evidence that those who adopt sustainable practices often establish social ties and networks with other sustainable farming practitioners to better facilitate idea and knowledge exchange (Bell, 2004; Carolan, 2006b; Hassanein, 1999). Organizations and networks of farmers who practice sustainability are a primary way for this to happen. Sustainable agriculture becomes socially possible as a practice through such organizations because they act as informational and conversational venues for farmers interested in sustainability to engage with each other. The reason for such organizations and networks may be in part because farmers, especially members of sustainable agriculture organizations, see low governmental support for sustainable farming methods, prompting them to rely instead primarily on each other and their personal experience for information about sustainable practices (Carolan, 2005, 2006a).

So, does local food promote social responsibility, particularly in terms of equitable access to food, increased public health, and stronger social ties? In

\footnotetext{
${ }^{18}$ Abaidoo and Dickinson (2002) argue that sustainable and conventional agricultural systems themselves are founded upon fundamentally different paradigms.
}

short, it can, though as DuPuis and Goodman (2005) and others remind us, this is but one possible outcome of local food and not an inherent one. Without reflexive engagement in the part of consumers and producers, locally based food systems are just as likely to promote inequitable access as they are food security. Similarly, local food has the power to provide public health benefits, but only inasmuch as it is systematically developed as an alternative to the industrial food supply. And it is possible that local food systems could promote stronger ties within a community, but this is not necessarily so (nor even the most important aspect of social responsibility). Locally based food systems, then, may have great potential for promoting the socially responsible leg of sustainability, with the important caveat that such systems (as with most methods of promoting social responsibility) require significant reflexive and systematic engagement.

\section{Conclusion: The Individualistic Error}

There is one more potential pitfall inherent to the claims of a nonreflexive localism that can be found woven throughout all of the various claims made about locally based food systems; I call it the individualistic error. Many scholars and advocates of localism (including Kloppenburg and colleagues as well as Brian Halweil (2002) and Colin Hines and colleagues (see Hines, 2000, and Hines, Lucas, \& Shiva, 2002)) reason that if people know how problematic conventional food is in its production process, they will seek out better food sources. While there is evidence to suggest that this may be true in some instances (for example, regarding fear of food contamination, see Blay-Palmer, 2008, Fromartz, 2006, and Nestle, 2007), education on these issues is not enough; instead we need institutional change and social network reconfiguration to see a true shift to sustainable systems (see Carolan, 2005, 2006a). Even within sustainable agriculture organizations, this is not an easy line to walk (Campbell, 2001). In their calls for greater awareness and education on the problems of global food production, such advocates have a tendency to oversimplify awareness of these problems with a 
logical shift toward sustainability. ${ }^{19}$ In short, individual-level solutions are not effective for dealing with structural problems (Szasz, 2009). Recall, for example, the government subsidies geared toward certain crops but not others, or the fact that our severe overproduction of food indicates that hunger, domestically and abroad, is caused not by lack of food but by inequality and inability to access it. These problems will not be resolved by convincing people of the wonderfulness of local (or even sustainable) agriculture.

In considering the shift from an industrial to a sustainable food system, Blay-Palmer (2008) argues that "there are usually no clear boundaries between [industrial and alternative food] systems. More often it is the case that the two systems overlap. At the very least, they are both contained within the same regulatory frameworks that serve to reinforce and constrain certain features of both systems" (p. 134; emphasis added). To become more than marginal, niche spaces in the food system, proponents of alternative agriculture systems will have to work with and within the governmental regulatory frameworks that govern the broader system of food production. Political support for a locally based food system, then, is more than simply a local matter:

First, a territorial and not a sectoral approach is needed to integrate agriculture with other elements....Second, decisions made about food systems need to be founded in subsidiarity, that is decisions should be made as low down the governmental hierarchy as possible. And third, to make this effective and relevant, consultation is needed to empower people as part of the process and to ensure that reflexivity is built into the process. (Blay-Palmer, 2008, p. 151)

Throughout this article I have attempted to walk a fine line between highlighting the potential

${ }^{19}$ Johnston (2008) highlights a related case to this shortcoming in her study of the citizen-consumer concept as it relates to shopping at Whole Foods. Though the citizen-consumer concept encompasses the belief that how you shop can promote social change, the citizen-consumer is likewise inconsistent with growth-oriented capitalism. benefits and solutions of a locally based food system and pointing out the potential pitfalls and shortcomings of adopting such an approach uncritically. I believe that despite all the complexity and uncertainty, there are a few things about which we can be very clear. First, the conventional industrial food systems we have today are not sustainable; this is true regardless of which leg of sustainability one considers. Second, locally and regionally based agriculture systems have great potential to resolve or remediate many of the conventional systems' problems, most notably through a reduction of transportation distances, a remediation of food inequalities, an ability to be regionally (though not totally) self-reliant, and a way out of the economic and social risks of global-industrial agriculture. Nevertheless, we should not assume that such systems offer an inherently sustainable solution. Meeting the promise of sustainability through locally based food systems will require not only the active engagement of reflexive consumers and reflexive producers, but also structural and systemic changes to the ways in which our food is produced and distributed.

\section{Acknowledgements}

Special thanks to Joya Misra, Leslie King, Jen Lundquist, and the members of the UMass "Write@Soc" group for feedback, insights, and general support when continuing to write was most challenging. Thanks as well to several anonymous reviewers for some much needed sharp and critical feedback.

\section{References}

Abaidoo, S., \& Dickinson, H. (2002). Alternative and conventional agricultural paradigms: Evidence from farming in southwest Saskatchewan. Rural Sociology, 67(1), 114-131. http://dx.doi.org/10.1111/j.15490831.2002.tb00096.x

Allen, P. (Ed.). (1993). Food for the future: Conditions and contradictions of sustainability. New York: John Wiley and Sons.

Allen, P. (2004). Together at the table: Sustainability and sustenance in the American agrifood system. University Park, Pennsylvania: The Pennsylvania State University System. 
Altekruse, S. F., Cohen, M. L., \& Swerdlow, D. L. (1997). Emerging foodborne diseases. Emerging Infectious Diseases, 3(3), 285-293. http://dx.doi.org/10.3201/eid0303.970304

Altieri, M. A. (1995). Agroecology: The science of sustainable agriculture. Boulder, Colorado: Westview Press.

Andrews, R. N. L. (2006). Managing the environment, managing ourselves (2nd Ed.). New Haven, Connecticut: Yale University Press.

Belasco, W. (2007 [1989]). Appetite for change: How the counterculture took on the food industry. Ithaca, New York: Cornell Paperbacks.

Bell, M. M. (2004). An invitation to environmental sociology (2nd ed.). Thousand Oaks, California: Pine Forge Press.

Blay-Palmer, A. (2008). Food fears: From industrial to sustainable food systems. Burlington, Vermont: Ashgate.

Bonanno, A., Busch, L., Friedland, W. H., Gouveia, L., \& Mingione, E. (1994). From Columbus to Con Agra: The globalization of agriculture and food. Lawrence, Kansas: University Press of Kansas.

Bonanno, A., \& Constance, D. H. (2006). Corporations and the state in the global era: The case of Seaboard Farms and Texas. Rural Sociology, 71(1), 59-84.

Bond, J. K., Thilmany, D., \& Bond, C. A. (2006). Direct marketing of fresh produce: Understanding consumer purchasing decisions. Choices: The magazine of food, farm, and resource issues, 21(4), 229-235. http://purl.umn.edu/94359

Born, B., \& Purcell, M. (2006). Avoiding the local trap. Journal of Planning and Research, 26(2), 195-207. http://dx.doi.org/10.1177/0739456X06291389

Brodt, S., Feenstra, G., Kozloff, R., Klonsky, K., \& Tourte, L. (2006). Farmer-community connections and the future of ecological agriculture in California. Agriculture and Human V alues, 23(1), 7588. http://dx.doi.org/10.1007/s10460-004-5870-y

Brown, C. (2003). Consumers' preferences for locally produced food: A study in southeast Missouri. American Journal of Alternative Agriculture, 18(4), 213 224. http://dx.doi.org/10.1079/AJAA200353

Bureau of Labor Statistics [BLS]. (2010, May). Occupational employment and wage estimates. U.S. Department of Labor. Available at http://www.bls.gov/oes/oes dl.htm
Buttel, F. H., Larson, O. F., \& Gillespie, G. W. (1990). The sociology of agriculture. New York: Greenwood Press.

Campbell, D. (2001). Conviction seeking efficacy: Sustainable agriculture and the politics of cooptation. Agriculture and Human Values, 18(4), 353-363.

Carolan, M. S. (2005). Barriers to the adoption of sustainable agriculture on rented land: An examination of contesting social fields. Rural Sociology, 70(3), 387-413.

Carolan, M. S. (2006a). Do you see what I see? Examining the epistemic barriers to sustainable agriculture. Rural Sociology, 71(2), 232-260.

Carolan, M. S. (2006b). Social change and the adoption and adaptation of knowledge claims: Whose truth do you trust in regard to sustainable agriculture? Agriculture and Human Values, 23(3), 325-339.

Cochrane, W. (2003). The curse of American agricultural abundance: A sustainable solution. Lincoln, Nebraska: University of Nebraska Press.

Cone, C. A., \& Myhre, A. (2000). Community supported agriculture: A sustainable alternative to industrial agriculture? Human Organization, 59(2), 187-197.

Connolly, J., \& Prothero, A. (2008). Green consumption: Life-politics, risk, and contradictions. Journal of Consumer Culture, 8(1), 117-145. http://dx.doi.org/10.1177/1469540507086422

Crews, T. E., Mohler, C. L., \& Power, A. G. (1991). Energetics and ecosystem integrity: The defining principles of sustainable agriculture. American Journal of Alternative Agriculture, 6(3), 146-149. http://dx.doi.org/10.1017/S0889189300004124

Cuddeford, V. (2003). When organics go mainstream. Alternatives Journal, 29(4), 14-19.

Deaton, B. J., \& Hoehn, J. P. (2005). The social construction of production externalities in contemporary agriculture: Process versus product standards as the basis for defining "organic." Agriculture and Human Values, 22(1), 31-38. http://dx.doi.org/10.1007/s10460-004-7228-x

DeLind, L. B. (1999). Close encounters with a CSA: The reflections of a bruised and somewhat wiser anthropologist. Agriculture and Human V alues, 16(1), 3-9. http://dx.doi.org/10.1023/A:1007575521309

DeLind, L. B. (2002). Place, work, and civic agriculture: Common fields for cultivation. Agriculture and Human Values, 19(3), 217-224. 
DeLind, L. B., \& Ferguson, A. E. (1999). Is this a women's movement? The relationship of gender to CSA in Michigan. Human Organization, 58(2), 190200.

DeLind, L. B., \& Howard, P. H. (2008). Safe at any scale? Food scares, food regulation, and scaled alternatives. Agriculture and Human V alues, 25(3), 301-317. http://dx.doi.org/10.1007/s10460-0079112-y

DuPuis, E. M. (2002). Nature's perfect food: How milk became America's drink. New York: New York University Press.

DuPuis, E. M., \& Goodman, D. (2005). Should we go "home" to eat?: Toward a reflexive politics of localism. Journal of Rural Studies, 21(3), 359-371. http://dx.doi.org/10.1016/j.jrurstud.2005.05.011

DuPuis, E. M., Goodman, D., \& Harrison, J. (2006). Just values or just value? Remaking the local in agro-food studies. In T. Marsen, \& J. Murdoch (Eds.), Between the local and the global: Confronting complexity in the contemporary agri-food sector (pp. 241268). Research in Rural Sociology and Development, Vol. 12. San Diego, California: JAI Press.

Duram, L. (2005). Good growing: Why organic farming works. Lincoln, Nebraska: University of Nebraska Press.

Duram, L., \& Oberholtzer, L. (2010). A geographic approach to place and natural resource use in local food systems. Renewable Agriculture and Food Systems, 25(2), 99-108. http://dx.doi.org/10.1017/S1742170510000104

Edwards-Jones, G., Milà i Canals, L., Hounsome, N., Truninger, M., Koerber, G., Barry Hounsome,... Jones, D. L. (2008). Testing the assertion that "local food" is best: The challenges of an evidence-based approach. Trends in Food Science and Technology, 19(5), 265-274. http://dx.doi.org/10.1016/j.tifs.2008.01.008

Enshayan, K. (2004). Local food, local security. Renewable Agriculture and Food Systems, 19(1), 2. http://dx.doi.org/10.1079/RAFS200359

Feenstra, G. (1997). Local food systems and sustainable communities. American Journal of Alternative Agriculture, 12(1), 28-36. http://dx.doi.org/10.1017/S0889189300007165
Feenstra, G., Ingels, C., \& Campbell, D. (n.d.) What is sustainable agriculture? University of California Sustainable Agriculture Research and Education Program. Available at http://www.sarep.ucdavis.edu/concept.htm

Fonte, M. (2008). Knowledge, food, and place. A way of producing, a way of knowing. Sociologia Ruralis, 48(3), 200-222. http://dx.doi.org/10.1111/j.14679523.2008.00462.x

Friedmann, H. (2002). The international political economy of food: A global crisis. In C. M. Counihan (Ed.), Food in the USA: A reader (pp. 325-346). New York: Routledge.

Fromartz, S. (2006). Organic, Inc.: Natural foods and how they grew. Orlando, Florida: Harcourt.

Gellerman, B., \& Curwood, S. (2007, 3 November). Diet for a dying planet. From the radio broadcast Living on Earth, a program sponsored by National Public Radio. Transcript at http://www.loe.org/shows/ segments.htm?programID =07-P13-00044\& $\underline{\text { segmentID }=6}$

Getz, A. (1991). Urban foodsheds. The Permaculture Activist, 24(October), 26-27.

Gibson-Graham, J. K. (2010). Post-development possibilities for local and regional development. In A. Pike, A. Rodriguez-Pose, \& J. Tomaney (Eds.), Handbook of local and regional development (pp. 226236). London: Routledge.

Glaeser, B. (1997). Environment and developing countries. In M. Redclift \& G. Woodgate (Eds.), The international handbook of environmental sociology (pp. 101-118). Northampton, Massachusetts: Edward Elgar Press.

Goldschmidt, W. (1946). Small business and the community. Report of the Smaller War Plants Corporation to the Special Committee to Study Problems of American Small Business. Washington, D.C.: U.S. Government Printing Office.

Guthman, J. (2004a). Agrarian dreams: The paradox of organic farming in California. Berkeley and Los Angeles: University of California Press.

Guthman, J. (2004b). The trouble with "Organic Lite" in California: A rejoinder to the "conventionalisation” debate. Sociologia Ruralis, 44(3), 301-316. http://dx.doi.org/10.1111/j.1467-9523.2004. 00277.x 
Guthman, J., Morris, A. W., \& Allen, P. (2006). Squaring farm security and food security in two types of alternative food institutions. Rural Sociology, 71(4), 662-684.

Hall, A., \& Mogyorody, V. (2007). Organic farming, gender, and the labor process. Rural Sociology, 72(2), 289-316.

Halweil, B. (2002). Home grown: The case for local food in a global market. Washington, D.C.: Worldwatch Institute.

Hassanein, N. (1999). Changing the way America farms: Knowledge and community in the sustainable agriculture movement. Lincoln, Nebraska: University of Nebraska Press.

Hedden, W. P. (1929). How great cities are fed. New York: D. C. Heath \& Co.

Heller, M. C., \& Keoleian, G. A. (2003). Assessing the sustainability of the U.S. food system: A life cycle perspective. Agricultural Systems, 76(3), 1007-1041.

Henderson, E., with Van En, R. (2007). Sharing the barvest: A citizen's guide to community supported agriculture (Revised and Expanded). White River Junction, Vermont: Chelsea Green Publishing.

Hess, D. J. (2009). Localist movements in a global economy: Sustainability, justice, and urban development in the United States. Cambridge, Massachusetts: Massachusetts Institute of Technology (MIT) Press.

Hines, C. (2000). Localization: A global manifesto. London: Earthscan Publications.

Hines, C., Lucas, C., \& Shiva, V. (2002). Local food, global solution. The Ecologist, 32(5), 38-40.

Hinrichs, C. C. (2000). Embeddedness and local food systems: notes on two types of direct agricultural market. Journal of Rural Studies, 16(3), 295-303.

Hinrichs, C. C. (2003). The practice and politics of food system localization. Journal of Rural Studies, 19(1), 33-45. http://dx.doi.org/10.1016/S0743-0167(02) 00040-2

Hinrichs, C., \& Kremer, K. S. (2008). Social inclusion in a Midwest local food system project. Journal of Poverty, 6(1), 65-90. http://dx.doi.org/10.1300/J134v06n01 04

Howard, P. (2009). Consolidation in the North American organic food processing sector, 1997 to 2007. International Journal of Sociology of Agriculture and Food, 16(1), 13-30.
Institute of Agriculture and Natural Resources [ANR]. (2003). Approaching foodservice establishments with locally grown products. Lincoln, Nebraska: Food Processing Center, University of Nebraska.

Ikerd, J. (2007). On defining sustainable agriculture. North Carolina Sustainable Agriculture Research and Education Program. Retrieved from http://www.sustainable-ag.ncsu.edu/ onsustaibableag.htm

Iles, A. (2005). Learning in sustainable agriculture: Food miles and missing objects. Enrionmental $V$ alues, 14(2), 163-183. http://dx.doi.org/10.3197/0963271054084894

Izumi, B. T., Rostant, O. S., Moss, M. J., \& Hamm, M. W. (2006). Results from the 2004 Michigan Farmto-School Survey. Journal of School Health, 76(5), 169-174. http://dx.doi.org/10.1111/i.1746-1561. 2006.00090.x

Jennings, P. (2003, 8 December). How to get fat without really trying. ABC New Special Report.

Johnston, J. (2008). The citizen-consumer hybrid: Ideological tensions and the case of Whole Foods Market. Theory and Society, 37(3), 229-270. http://dx.doi.org/10.1007/s11186-007-9058-5

Kaup, B. Z. (2008). The reflexive producer: The influence of farmer knowledge upon the use of $\mathrm{Bt}$ corn. Rural Sociology, 73(1), 62-81.

Kloppenburg Jr., J., Hendrickson, J., \& Stevenson, G. W. (1996). Coming into the foodshed. Agriculture and Human Values, 13(3), 33-44.

Kloppenburg Jr., J., \& Lezberg, S. (1996). Getting it straight before we eat ourselves to death: From food system to foodshed in the $21^{\text {st }}$ century. Society and Natural Resources, 9, 93-96. http://dx.doi.org/10.1080/08941929609380954

Knight, A. J., \& Warland, R. (2005). Determinants of food safety risks: A multi-disciplinary approach. Rural Sociology, 70(2), 253-275.

Kremen, A., Greene, C., \& Hanson, J. (2003). Organic produce, price premiums, and eco-labeling in U.S. farmers' markets (Report VGS 301-01). Washington, D.C.: USDA Economic Research Service.

Lang, T. (1996). Food security: Does it conflict with globalization? Development, 4, 45-50.

Lea, E. (2005). Food, health, the environment, and consumers' dietary choices. Nutrition and Dietetics, 62(1), 21-25. http://dx.doi.org/10.1111/j.17470080.2005.tb00005.x 
Lezberg, S., \& Kloppenburg, J. (1996). That we all might eat: Regionally-reliant food systems for the $21^{\text {st }}$ century. Development, 4, 28-33.

Lobao, L., \& Meyer, K. (2001). The great agricultural transition: Crisis, change, and social consequences of twentieth century U.S. farming. Annual Review of Sociology, 27, 103-124. http://dx.doi.org/10.1146/annurev.soc.27.1.103

Lobao, L. M., Schulman, M. D., \& Swanson, L. E. (1993). Still going: Recent debates on the Goldschmidt Hypothesis. Rural Sociology, 58(2), 277-288. http://dx.doi.org/10.1111/i.15490831.1993.tb00495.x

Lyson, T. (2004). Civic agriculture: Reconnecting farm, food, and community. Medford, Massachusetts/Hanover, New Hampshire: Tufts University Press/University Press of New England.

Lyson, T. A., \& Guptill, A. (2004). Commodity agriculture, civic agriculture, and the future of U.S. farming. Rural Sociology, 69(3), 370-385.

MacCannell, D. (1988). Industrial agriculture and rural community degradation. In L. E. Swanson (Ed.), Agriculture and community change in the U.S. (pp. 1575). Boulder, Colorado: Westview Press.

MacCannell, D., \& White, J. (1984). The social costs of large-scale agriculture: The prospects of land reform in California. In C. C. Geisler \& F. J. Popper (Eds.), Land reform, American style (pp. 3554). Totowa, New Jersey: Rowman \& Allenheld.

Mancus, P. (2007). Nitrogen fertilizer dependency and its contradictions: A theoretical exploration of social-ecological metabolism. Rural Sociology, 72(2), 269-288.

McDonald, J. H. (2002). NAFTA and basic food production: Dependency and marginalization on both sides of the US/Mexico border. In C. M. Counihan (Ed.), Food in the USA: A reader (pp. 359372). New York: Routledge.

Meares, A. C. (1997). Making the transition from conventional to sustainable agriculture: Gender, social movement participation, and quality of life on the family farm. Rural Sociology, 62(1), 21-47. http://dx.doi.org/10.1111/j.1549-0831.1997. tb00643.x

Murray, S. (2007). Moveable feasts: From ancient Rome to the $21^{\text {st }}$ century, the incredible journeys of the food we eat. New York: St. Martin's Press.
Nestle, M. (2002). Hunger in the United States: Policy implications. In C. M. Counihan (Ed.), Food in the US A: A reader (pp. 386-399). New York: Routledge.

Nestle, M. (2007). Food politics: How the food industry influences nutrition and health (Revised Ed.). Berkeley: University of California Press.

Nierenberg, D. (2003). Factory farming in the developing world. World Watch, 16(3), 10-19.

Norberg-Hodge, H. (1998). Think global - eat local! Delicious ways to counter globalization. The Ecologist, 28(4), 208-214.

O'Hara, S. U., \& Stagl, S. (2001). Global food markets and their local alternatives: A socio-ecological economic perspective. Population and Environment, 22(6), 533-554. http://dx.doi.org/10.1023/A:1010795305097

Obach, B. (2007). Theoretical interpretations of the growth in organic agriculture: Agricultural modernization or an organic treadmill? Society and Natural Resources, 20(3), 229-244.

Oglethorpe, D. (2010). Food miles - The economic, environmental, and social significance of the focus on local food. CAB International: Perspectives in Agriculture, Veterinary Science, Nutrition, and Natural Resources, 4, 72.

Organic Trade Association [OTA]. (2010). Organic industry survey. Summary available at http://www.ota.com/pics/documents/2010 OrganicIndustrySurveySummary.pdf

Paxton, A. (1994). The food miles report: The dangers of long distance food transport. London: SAFE.

Peter, G., Bell, M. M., Jarnagin, S., \& Bauer, D. (2000). Coming back across the fence: Masculinity and the transition to sustainable agriculture. Rural Sociology, 65(2), 215-233. http://dx.doi.org/10.1111/j.1549_ 0831.2000.tb00026.x

Peters, C. J., Bills, N. L., Wilkins, J. L., \& Fick, G. W. (2008). Foodshed analysis and its relevance to sustainability. Renewable Agriculture and Food Systems 24(1): 1-7.

Peters, C., Bills, N., Wilkins, J., \& Smith, R. D. (2002). $V$ egetable consumption, dietary guidelines, and agricultural production in New York State: Implications for local food economies. Ithaca, New York: Cornell University Department of Applied Economics and Management. 
Pirog, R., van Pelt, T., Enshayan, K., \& Cook, E. (2001). Food, fuel, and freeways: An Iowa perspective on how far food travels. Ames, Iowa: Leopold Center for Sustainable Agriculture.

Pollan, M. (2001, 13 May). Naturally: How organic became a marketing niche and a multibillion dollar industry. New York Times Magazine, 630-641. Retrieved from http://www.nytimes.com/2001/ $05 / 13 /$ magazine $/$ naturally.html? scp $=2 \&$ sq $=$ $\underline{\text { michael }+ \text { pollan\&st }=\text { nyt }}$

Pollan, M. (2006). The omnivore's dilemma: A natural history of four meals. New York: The Penguin Press.

Rasmussen, W. D., Baker, G. L., \& Ward, J. S. (1976). A short bistory of agricultural adjustment, 1933-75 (Agriculture Information Bulletin No. 391). Washington, D.C.: U.S. Department of Agriculture Economic Research Service.

Raynolds, L. T. (2000). Re-embedding global agriculture: The international organic and fair trade movements. Agriculture and Human Values, 17(3), 297-309.

Raynolds, L. T. (2004). The globalization of organic agro-food networks. World Development, 32(5), 725743.

http://dx.doi.org/10.1016/j.worlddev.2003.11.008

Rittel, H. W. J., \& Webber, M. W. (1973). Dilemmas in a general theory of planning. Policy Sciences, 4(2), 155169. http://dx.doi.org/10.1007/BF01405730

Rosset, P. M. (1999). The multiple functions and benefits of small farm agriculture (Policy Brief No. 4). Oakland, California: Food First.

Schnaiberg, A. (1980). The environment, from surplus to scarcity. New York and Oxford: Oxford University Press.

Schnaiberg, A., \& Gould, K. A. (1994). Environment and society: The enduring conflict. New York: St. Martin's Press.

Schneider, M. L., \& Francis, C. A. (2005). Marketing locally produced foods: Consumer and farmer opinions in Washington County, Nebraska. Renewable Agriculture and Food Systems, 20(4), 252260. http://dx.doi.org/10.1079/RAF2005114

Selfa, T., \& Qazi, J. (2005). Place, taste, or face-to-face? Understanding producer-consumer networks in "local" food systems in Washington State. Agriculture and Human Values, 22(4), 451-464. http://dx.doi.org/10.1007/s10460-005-3401-0
Sonnino, R. (2009). Escaping the local trap: Insights on re-localization from school food reform. Journal of Environmental Policy and Planning, 12(1), 23-40.

Starr, A., Card, A., Benepe, C., Auld, G., Lamm, D., Smith, K., \& Wilken, K. (2003). Sustaining local agriculture: Barriers and opportunities to direct marketing between farms and restaurants in Colorado. Agriculture and Human Values, 20(3), 301321.

Stephenson, G., \& Lev, L. (2004). Common support for local agriculture in two contrasting Oregon communities. Renewable Agriculture and Food Systems, 19(4), 210-217. http://dx.doi.org/10.1079/RAFS200481

Szasz, A. (2009). Shopping our way to safety: How we changed from protecting the environment to protecting ourselves. Minneapolis: University of Minnesota Press.

Tauxe, R. V. (1997). Emerging foodborne diseases: An evolving public health challenge. Emerging Infectious Diseases, 3(4), 425-434. http://dx.doi.org/10.3201/eid0304.970403

Thilmany, D., \& Watson, P. (2004). The increasing role of direct marketing and farmers markets for western US producers. Western Economics Forum, April, 19-25.

Thompson Jr., E., Harper, A. M., \& Kraus, S. (2008). Think globally_Eat locally: San Francisco foodshed assessment. American Farmland Trust. Retrieved from http://www.farmland.org/programs/ states/ca/Feature \%20Stories/San-FranciscoFoodshed-Report.asp

Trauger, A. (2004). Because they can do the work: Women farmers in sustainable agriculture in Pennsylvania, USA. Gender, Place, and Culture, 11(2), 289-307.

http://dx.doi.org/10.1080/0966369042000218491

Union of Concerned Scientists. (2004). Close to home: Support your local farmer. Earthwise, 6(4), 1.

U.S. Department of Agriculture. (2009). The 2007 Census of Agriculture. National Agriculture Statistics Service. Available at http://www.agcensus.usda.gov/

Vallianatos, M., Gottlieb, R., \& Haase, M. A. (2004). Farm-to-school: Strategies for urban health, combating sprawl, and establishing a community food systems approach. Journal of Planning Education and Research, 23(4), 414-423. http://dx.doi.org/10.1177/0739456X04264765 
Vogt, R. A., \& Kaiser, L. L. (2008). Still a time to act: A review of institutional marketing of regionallygrown food. Agriculture and Human Values, 25(2), 241-255. http://dx.doi.org/10.1007/s10460-0079106-9

Walker, R. (2004). The conquest of bread: 150 years of agribusiness in California. New York: The New Press.

Waltner-Toews, D. (1996). An agroecosystem perspective on foodborne illnesses. Ecosystem Health, 2(3), 177-185.

Warman, A. (N. L. Westrate, Trans.). (2003). Corn and capitalism: How a botanical bastard grew to global dominance. Chapel Hill: University of North Carolina Press.

Weber, C. L., \& Matthews, H. S. (2008). Food-miles and the relative climate impacts of food choices in the United States. Environmental Science and Technology, 42(10), 3508-3513. http://dx.doi.org/10.1021/es702969f
Wells, B. L., Gradwell, S., \& Yoder, R. (1999). Growing food, growing community: Community supported agriculture in rural Iowa. Community Development Journal, 34(1), 38-46. http://dx.doi.org/10.1093/cdj/34.1.38

Winter, M. (2003). Embeddedness, the new food economy, and defensive localism. Journal of Rural Studies, 19(1), 23-32. http://dx.doi.org/10.1016/S0743-0167(02)00053-0

Youngberg, G., Schaller, N., \& Merrigan, K. (1993). The sustainable agriculture policy agenda in the United States: Politics and prospects. In P. Allen (Ed.), Food for the future: Conditions and dontradictions of sustainability. New York: John Wiley and Sons. 